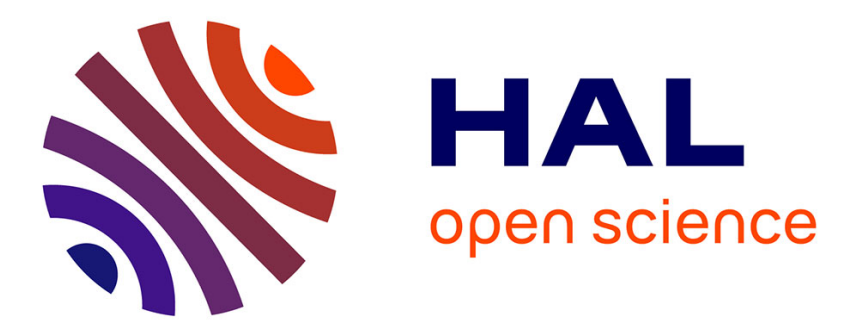

\title{
Protective effect of ellagic acid, a natural polyphenolic compound, in a murine model of Crohn's disease
}

\author{
M.A. Rosillo, M. Sanchez-Hidalgo, A. Cárdeno, C. Alarcón de La Lastra
}

\section{To cite this version:}

M.A. Rosillo, M. Sanchez-Hidalgo, A. Cárdeno, C. Alarcón de La Lastra. Protective effect of ellagic acid, a natural polyphenolic compound, in a murine model of Crohn's disease. Biochemical Pharmacology, 2011, 82 (7), pp.737. 10.1016/j.bcp.2011.06.043 . hal-00723637

\section{HAL Id: hal-00723637 \\ https://hal.science/hal-00723637}

Submitted on 12 Aug 2012

HAL is a multi-disciplinary open access archive for the deposit and dissemination of scientific research documents, whether they are published or not. The documents may come from teaching and research institutions in France or abroad, or from public or private research centers.
L'archive ouverte pluridisciplinaire HAL, est destinée au dépôt et à la diffusion de documents scientifiques de niveau recherche, publiés ou non, émanant des établissements d'enseignement et de recherche français ou étrangers, des laboratoires publics ou privés. 


\section{Accepted Manuscript}

Title: Protective effect of ellagic acid, a natural polyphenolic compound, in a murine model of Crohn's disease

Authors: M.A. Rosillo, M. Sanchez-Hidalgo, A. Cárdeno, C. Alarcón de la Lastra

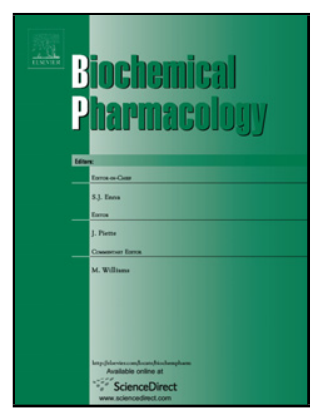

PII:

S0006-2952(11)00427-8

DOI: doi:10.1016/j.bcp.2011.06.043

Reference: BCP 10968

To appear in: $B C P$

Received date: 1-4-2011

Revised date: 29-6-2011

Accepted date: $30-6-2011$

Please cite this article as: Rosillo MA, Sanchez-Hidalgo M, Cárdeno A, Lastra CA, Protective effect of ellagic acid, a natural polyphenolic compound, in a murine model of Crohn's disease, Biochemical Pharmacology (2010), doi:10.1016/j.bcp.2011.06.043

This is a PDF file of an unedited manuscript that has been accepted for publication. As a service to our customers we are providing this early version of the manuscript. The manuscript will undergo copyediting, typesetting, and review of the resulting proof before it is published in its final form. Please note that during the production process errors may be discovered which could affect the content, and all legal disclaimers that apply to the journal pertain. 
Protective effect of ellagic acid, a natural polyphenolic compound, in a murine model of Crohn's disease

\author{
Rosillo MA*, Sanchez-Hidalgo M*, Cárdeno A, Alarcón de la Lastra C \\ Department of Pharmacology, Faculty of Pharmacy, University of Seville. Profesor \\ García González Street 2, 41012 Seville, Spain.
}

*, These authors contributed equally to this work

Address correspondence to:

Catalina Alarcón de la Lastra Romero

Department of Pharmacology.

Faculty of Pharmacy, University of Seville.

Profesor García Gonzalez Street 2.

41012 Seville (Spain)

Tel: +34 954559877

Fax: +34954 556074

E-mail: calarcon@us.es 


\section{ABSTRACT}

Current epidemiological and experimental studies support a beneficial role of dietary polyphenols in several gastrointestinal diseases, including inflammatory bowel disease. The aim of this study was to gain a better understanding of the effects of a naturally occurring polyphenol, ellagic acid, present in some fruits such as pomegranate, raspberries and nuts among others, in an experimental murine model of Crohn's disease by intra-colonic administration of TNBS in rats. Analysis of the lesions were carried out by macroscopic and histological technics. Inflammation response was assessed by histology and myeloperoxidase activity. iNOS and COX-2 are upregulated by MAPKs and NF- $\mathrm{BB}$ nuclear transcription factor in intestinal epithelial cells thus, we determined the expression of iNOS, COX- 2 and the involvement of the p38, JNK, ERK1/2 MAPKs and NF- $\kappa$ B signalling in the protective effect of EA by western blotting. Oral administration of EA (10-20 mg/kg) diminished the severity and extension of the intestinal injuries induced by TNBS although there was no observed a significant doseresponse. In addition, EA increased mucus production in goblet cells in colon mucosa, decreased neutrophil infiltration and pro-inflammatory proteins COX-2 and iNOS overexpression. Also EA was capable of reducing the activation of $\mathrm{p} 38$, JNK and ERK1/2 MAPKs, preventing the inhibitory protein I $\kappa$ B-degradation and inducing an inhibition of the nuclear translocation level of p65 in colonic mucosa. In conclusion, EA reduces the damage in a rat model of Crohn's disease, alleviates the oxidative events and returns pro-inflammatory proteins expression to basal levels probably through MAPKs and NF- $\mathrm{BB}$ signalling pathways.

Keywords: Ellagic acid, TNBS, oxidative stress, COX-2, MAPK, NF-кB. 


\section{INTRODUCTION}

Inflammatory bowel disease (IBD) represents a socially and clinically relevant disorder, characterized by intestinal chronic inflammation. The major forms of idiopathic IBD, include ulcerative colitis and Crohn's disease. Although the aetiology of IBD is unclear, both $\mathrm{UC}$ and $\mathrm{CD}$ are believed to be T-cell-driven process with inflammatory resulting inappropriate cytokine production by subsets of CD4+ T-helper (Th) cells. Specifically, UC is associated with Th2 cells whereas CD is associated with Th1 and Th17 cytokines profile. Besides, many authors have reported that T-regulatory (Treg) cells expressing fork-head box P3 (FOXP3) and or IL-10 have a fundamental role in maintaining gut immune homeostasis. Furthermore, defects in the T-cellmediated regulatory processes have been suggested in prevention of inflammatory responses [1]. A complex system of intracellular signalling molecules such as mitogenactivated protein kinases (MAPKs) or the transcription factor nuclear factor $\kappa \mathrm{B}(\mathrm{NF}-$ $\kappa \mathrm{B})$, influences this uncontrolled immune system activation and inflammation by ultimately modulating gene transcription [2].

Predominantly innate immune cells such as neutrophils, monocytes, lymphocytes and macrophages are the main protagonists. Migration and activation of these into target mucosal tissues depends on the expression of Th-1 and Th-2 cytokines, several chemokines and adhesion molecules [3]. These cells generate an arsenal of aggressive metabolites and inflammatory mediators, key effectors of the increase of epithelial permeability and inflammation, resulting in tissue damage. Such mediators comprise histamine, reactive oxygen species (ROS), matrix metalloproteinases, and other proteases [4]. Likewise, the upregulation of certain proteins, i.e. cyclo-oxygenase 
(COX)-2 and inducible nitric oxide synthase (iNOS) has also been implicated and considered important determinants of colonic damage [5,6].

Current epidemiological and experimental studies support a beneficial role of dietary polyphenols in several gastrointestinal diseases, including IBD. Polyphenols have indeed shown anti-inflammatory properties and thus, could contribute, as complementary approaches to the conventional already existing therapeutic strategies (i.e. non-steroidal anti-inflammatory drugs) to the management of IBD.

Ellagic acid (EA) is a naturally occurring plant phenol found in certain fruits, nuts and vegetables, for example berries and pomegranate. Over the last few years, a number of in vivo and in vitro studies have provided evidence of important pharmacological properties including antioxidant, anti-inflammatory $[7,8,9,10,11]$ and anticarcinogenic activities $[12,13,14]$.

Previous reports, have documented that microspheres of ellagic acid [15] and a Punica granatum extract in addition to its ellagic acid rich fraction [16] decreased the degree of inflammation associated with experimental dextran sulphate sodium (DSS)induced colitis. Intra-colonic administration of trinitrobenzene sulfonic acid (TNBS) is one of standardized methods to produce an experimental model of IBD, which closely mimic the clinical and morphological features of IBD in particular Crohn's disease [17]. Thus, the aim of this study has been to gain a better understanding of the effects and mechanisms of action of ellagic acid during early colonic inflammation in rats caused by TNBS instillation in rats. Inflammation response was assessed by histology and myeloperoxidase activity (MPO), an index of neutrophil infiltration in the mucosa. We also determined the expression of iNOS, and COX-2 in colon mucosa by western blotting. 
$\mathrm{NF}-\kappa \mathrm{B}$ dimers are kept in an inactive cytoplasmic complex by inhibitory proteins, the inhibitor protein kappa B $(\mathrm{I} \kappa \mathrm{B})$ family, in resting cells. Phosphorylation of $\mathrm{I} \kappa \mathrm{B}$ generally leads to the rapid dissociation of the complex accompanied by proteolytic degradation of $\mathrm{I} \kappa \mathrm{B}$ and release of NF- $\kappa \mathrm{B}$ that subsequently transmigrate from cytoplasm into the nucleus. Furthermore, we studied IкB degradation as well as nuclear translocation levels of p65 and also the role of MAPKs (p38 MAPK, JNK and ERK1/2) signalling pathways in the beneficial effects of ellagic acid on acute colonic inflammation.

\section{MATERIAL AND METHODS}

\subsection{Experimental animals}

Male Wistar rats supplied by Animal Services, Faculty of Medicine, University of Seville, Spain, and weighing 180-220 g, were placed in a controlled room (temperature $24-25^{\circ} \mathrm{C}$, humidity $70-75 \%$, lighting regimen of $12 \mathrm{~L} / 12 \mathrm{D}$ ) and were fed a normal laboratory diet (Panlab, Barcelona, Spain). Rats were deprived of food for $24 \mathrm{~h}$ prior to the induction of colitis, but were allowed free access to tap water throughout. They were randomly assigned to groups of 10-11 animals. Experiments followed a protocol observed by the Animal Ethics Committee of the University of Seville and all experiments were in accordance with the recommendations of the European Union regarding animal experimentation (Directive of the European Counsel 86/609/EC).

\subsection{Induction of colitis}

Colitis was induced according to the procedure described by Morris et al. [18]. Briefly, rats were slightly anaesthetised with $12 \%$ chloral hydrate by intraperitoneal route 
following a $24 \mathrm{~h}$ fast, and then a medical-grade polyurethane canal for enteral feeding (external diameter $2 \mathrm{~mm}$ ) was inserted into the anus and the tip was advanced to $8 \mathrm{~cm}$ proximal to the anus verge. TNBS (Sigma-Aldrich Company Ltd. Spain) dissolved in $50 \%$ ethanol were instilled into the colon through the cannula $(10 \mathrm{mg}$ in a volume of $0.25 \mathrm{ml}$ to induce acute colitis). Following the instillation of the hapten, the animals were maintained in a head-down position for a few minutes to prevent leakage of the intracolonic instillate. Different control groups were created for comparison with TNBS/ethanol instillation: rats in the sham group received an enema of physiological saline instead of the TNBS solution, and ethanol group received $0.25 \mathrm{ml}$ of $50 \%$ ethanol. Ellagic acid (10 -20 mg/kg p.o; Sigma-Aldrich Company Ltd. Spain) was suspended in 0.1 Normal (N) $\mathrm{NaOH}$ solution and administered by gavage 48, 24 and $1 \mathrm{~h}$ prior to the induction of colitis and $24 \mathrm{~h}$ later. Control groups received vehicle in a comparable volume $(10 \mathrm{ml} / \mathrm{kg}$ animal). The rats were checked daily for behaviour, body weight, and stool consistency. Finally, animals were sacrificed, using an overdose of chloral hydrate $48 \mathrm{~h}$ after induction of colitis.

\subsection{Assessment of colitis}

The severity of colitis was evaluated by an independent observer who was blinded to the treatment. For each animal, the distal $10 \mathrm{~cm}$ portion of the colon was removed and cut longitudinally, slightly cleaned in physiological saline to remove faecal residues and weighed. Macroscopic inflammation scores were assigned based on clinical features of the colon [6]. The presence of adhesions (score 0-2), and/or stool consistency (score 01) were evaluated according to the criteria of Bobin-Dubigeon et al. [19]. Pieces of inflamed colon were collected and frozen in liquid nitrogen to measure biochemical parameters. 


\subsection{Histological studies}

For examination with the light microscope we used tissue samples from the distal colon of each animal fixed in $4 \%$ buffered paraformaldehyde, dehydrated in grade ethanol, and embedded in paraffin. Thereafter, sections of tissue were cut at $5 \mu \mathrm{m}$ on a rotary microtome (Leica Ultracut), mounted on clean glass slides and dried overnight at $37^{\circ} \mathrm{C}$. Sections were cleared, hydrated, and stained with haematoxylin and eosin, Giemsa, and Alcian blue for histological evaluation of colonic damage, cell infiltration and mucus content, respectively, according to standard protocols, and the slides were coded to prevent observer bias during evaluation. All tissue sections were examined in an Olympus BH-2 microscope for characterization of histopathological changes.

Photographs taken from colon samples were digitised using Kodak D290 Zoom camera Eastman Kodak Co., U.S.A. and Motic ${ }^{\circledR}$ Images 2000 release 1.1 (MicroOptic Industrial Group CO., LTD; B1 Series System Microscopes). Analysis of the figures was carried out by Adobe ${ }^{\circledR P h o t o s h o p}{ }^{\circledR}$ Version 5.0 (Adobe Systems) image analysis program.

\subsection{Assessment of leukocyte involvement}

MPO activity was assessed as a marker of neutrophil infiltration according to the methods of Grisham et al. [20] with slight modifications. In all animals one sample from the distal colon was obtained. Samples were excised from each animal and rapidly rinsed with ice-cold saline, blotted dry, and frozen at $-70{ }^{\circ} \mathrm{C}$. The tissue was thawed, weighed and homogenized in 10 volumes $50 \mathrm{mM}$ PBS, $\mathrm{pH}=7.4$. The homogenate was centrifuged at $20.000 \mathrm{~g}, 20 \mathrm{~min}, 4^{\circ} \mathrm{C}$. The pellet was again homogenized in 10 volumes $50 \mathrm{mM}$ PBS, $\mathrm{pH}=6.0$, containing $0.5 \%$ hexadecyl-trimethylammonium bromide 
(HETAB) and $10 \mathrm{mM}$ ethylenediamine tetraacetic acid (EDTA). This homogenate was subjected to one cycle of freezing/thawing and a brief period of sonication. The homogenate were diluted in 50 volumes of $50 \mathrm{mM}$ PBS, $\mathrm{pH} 6$. Then it was added consecutively $50 \mathrm{ml}$ of Odianisidine dihydrochloride $(0.067 \%)$, of HETAB $(0.5 \%)$ and of hydrogen peroxide $(0.003 \%)$. Each well containing the complete reaction mixture was incubated for $5 \mathrm{~min}$ in darkness. The changes in absorbance at $450 \mathrm{~nm}$ were measured with a microplate reader (Labsystem Multiskan EX, Helsinki, Finland). Results were quantified as U MPO/mg tissue.

\subsection{Isolation of cytoplasmic and nuclear proteins and immunoblotting detection}

Frozen colonic tissues were weighed and homogenized in ice-cold hypotonic buffer (1.5 $\mathrm{mM} \mathrm{MgCl} 2,10 \mathrm{Mm} \mathrm{KCl}, 0.2 \mathrm{mM}$ phenylmethylsulfonyl fluoride (PMSF), $1.0 \mathrm{mM}$ dithiothreitol (DTT) and $10 \mathrm{mM}$ Hepes, $\mathrm{pH}$ 7.9). Homogenates were incubated for $10 \mathrm{~min}$ on ice and centrifuged $\left(25,000 \times \mathrm{g}, 15 \mathrm{~min}, 4^{\circ} \mathrm{C}\right)$. Cytoplasmic proteins were collected from the supernatants and nuclear proteins from the pellets. These were washed once and centrifuged at $10,000 \times \mathrm{g}, 15 \mathrm{~min}, 4{ }^{\circ} \mathrm{C}$ ) after which they were suspended in ice-cold lowsalt buffer (25\% v/v glycerol, $1.5 \mathrm{mM} \mathrm{MgCl} 2,0.2 \mathrm{mM}$ EDTA, $0.2 \mathrm{mM}$ PMSF, $1.0 \mathrm{mM}$ DTT, KCl, Hepes, $\mathrm{pH}$ 7.9). Nuclear proteins were released by adding a high-salt buffer (25\% glycerol, 1.5 mM MgCl2, 0.2 mM EDTA, 0.2 mM PMSF, 1.0 mM DTT, 1.2 M $\mathrm{KCl}, 20 \mathrm{mM}$ Hepes, $\mathrm{pH}$ 7.9) drop by drop to a final concentration of $0.4 \mathrm{M} \mathrm{KCl}$. Samples were incubated on ice for $30 \mathrm{~min}$, with smooth shaking. Soluble nuclear proteins were recovered by centrifugation $\left(25,000 \times \mathrm{g}, 30 \mathrm{~min}, 4^{\circ} \mathrm{C}\right)$ and proteins were stored at $-80{ }^{\circ} \mathrm{C}$. Protein concentration of the homogenate was determined following Bradford's colorimetric method [21]. Aliquots of supernatant contains equal amount of protein (50 $\mu \mathrm{g}$ ) were separated on $10 \%$ acrilamide gel by sodium dodecyl sulfate-polyacryamide gel 
electrophoresis. In the next step, the proteins were electrophoretically transferred onto a nitrocellulose membrane and incubated with specific primary antibodies: rabbit polyclonal anti-COX-2 and anti-i-NOS (Cayman Chemical, USA) at dilution of 1:3000, rabbit polyclonal anti-IкB $\alpha$ (Cell Signalling Technology, USA) at dilution of 1:1000, rabbit polyclonal p65 (Santa Cruz Biotecnology, Inc) at dilution of 1:200, rabbit polyclonal anti-p-ERK1/2and mouse anti-ERK1/2 (Cell Signalling Technology, USA) at dilution of 1:2000, mouse polyclonal anti- JNK and anti-pJNK (Santa Cruz Biotecnology, Inc) at dilution of 1:200, and mouse polyclonal anti-p38 and anti-pp38 (Santa Cruz Biotecnology, Inc) at dilution of 1:100 and 1:1000, respectively, overnight at $4{ }^{\circ} \mathrm{C}$. After that, each filter was washed three times for $15 \mathrm{~min}$ and incubated with a horseradish peroxidise-labelled (HRP) secondary antibody anti-rabbit (Pierce Biotechnology, IL, USA) or anti-mouse (Dako Cytomation, USA) containing blocking solution for 1-2 $\mathrm{h}$ at room temperature. To prove equal loading, the blots were analyzed for $\beta$-actin expression using an anti- $\beta$-actin antibody (Sigma-Aldrich, MO, USA). Immunodetection was performed using enhanced chemiluminiscence light-detecting kit (SuperSignal ${ }^{\circledR}$ West Femto Chemiluminescent Substrate, Pierce, IL, USA). Densitometric data were studied following normalization to the control (housekeeping gene). The signals were analyzed and quantified by a Scientific Imaging Systems (KODAK 1D, Image Analysis Software).

\subsection{Data analysis}

All values in the figures and text are expressed as arithmetic means \pm standard error (S.E.M.). Data were evaluated with Graph Pad Prism ${ }^{\circledR}$ Version 2.01 software. The statistical significance of any difference in each parameter among the groups was evaluated by one-way analysis of variance (ANOVA), using Tukey-Kramer multiple comparisons test as post hoc test. $P$ values of $<0.05$ were considered statistically 
significant. In the experiment involving histology the figures shown are representative of at least six experiments performed on different days.

\section{RESULTS}

\subsection{Protective effects of ellagic acid in acute TNBS-induced colitis in rats.}

$48 \mathrm{~h}$ after intracolonic administration of TNBS, rats showed postration, piloerection and hypo motility. Macroscopic inspection of the cecum, colon and rectum showed evidence of severe colonic mucosal damage, with edema, deep ulcerations and haemorrhage.

Lesions in the distal colon were quantified using a macroscopic damage score (mean: $9.1 \pm 0.54$ ) (Fig. 1). Control animals underwent severe anorexia with a marked body weight loss compared with the sham animals. A significant increase of weight/length of the rat colon, an indicator of inflammation, and presence of adhesions to adjacent organs were frequently observed in TNBS-treated rats (Table 1).

Treatment of TNBS-rats with ellagic acid reduced the loss in body weight. There was a significant decrease in the weight/length relation of the ellagic acid-treated rats colon (Table 1) compared with TNBS-treated rats. In addition, the polyphenol at both doses assayed (10 and $20 \mathrm{mg} / \mathrm{kg}$ ), significantly attenuated the extent and severity of the colonic injury (Fig. 1).

\subsection{Histological studies of the colon after ellagic acid treatment on acute experimental TNBS model.}

On histological examination of the colon from sham-treated rats, the histological features of which were typical of a normal structure (Figs. 2A, 2B and 3A). The histopathological features included transmural necrosis, edema and diffuse 
inflammatory cells (polymorphonuclear leukocytes, lymphocytes, and eosinophils) infiltration in the mucosa (Fig. 3B). We assessed focal ulceration of the colonic mucosa extending through the muscularis mucosae as well as desquamated areas or loss of the epithelium (Figs. 2C, 2D and 3B). The architecture of the crypts was distorted and the lamina propria was thickened in peripheral areas of distorted crypts, especially in basal areas (Figs. 2C and 3B); some areas showed accumulation of mucus and cell remnants; however, Alcian blue-positive cells were less numerous. In addition, the mucin layer of the epithelium had disappeared (Fig. 2D).

Ellagic acid treatment caused an attenuation of morphological signs of cell damage and inflammatory cells were not found in lamina propria (Figs. 3C and 3D). In some areas, the epithelium remained intact (Fig. 2E) and the mucin layer was clearly visible with alcian blue-positive cells; these observations suggest the beginning of a reepithelization and healing process in ellagic acid- treated rats (Fig. 2F).

\subsection{Effect of ellagic acid on colonic leukocyte involvement in acute TNBS-induced colitis in rats.}

As shown in Fig. 4, a significant increase in MPO activity, an established marker for inflammatory cell infiltration, also characterized the colitis caused by TNBS $(7.63 \pm$ $0.92 \mathrm{U} \mathrm{MPO} / \mathrm{mg}$ tissue, $p<0.001 \mathrm{vs}$ sham group). Ellagic acid treatment (10 and $20 \mathrm{mg} / \mathrm{kg}$ ) showed a significant reduction in the degree of polymorphonuclear neutrophil infiltration. These results are consistent with histological findings.

\subsection{COX-2 and iNOS protein expressions are inhibited in colon tissue of TNBS- induced colitis by ellagic acid treatment.}


Cytosolic COX-2 and iNOS expression levels were measured by western blotting from colonic mucosa. Exposure of colon to TNBS caused strong expression of COX-2 and iNOS $(p<0.001)$, indicating that these proteins expression could be induced at the acute stage of colonic lesion caused by TNBS. Nevertheless, oral administration of ellagic acid was able to diminish significantly the up-regulation of both COX-2 and iNOS proteins (Figs. 5A, 5B).

\subsection{Ellagic acid prevents p38, JUNK and ERK1/2 MAPKs phosphorylation in acute TNBS-induced colitis in rats.}

Mitogen-activated protein (MAP) kinases transmit extracellular inflammatory signals into intracellular responses. These molecules play a key role in inducing gene expression which initiates inflammatory responses. We investigated the effect of ellagic acid on the TNBS-induced colitis activations of MAPKs (ERK, JNK, and p38). We investigated the effect of ellagic acid on the TNBS-induced colitis activations of MAPKs (ERK, JNK, and p38). TNBS was found to activate MAPKs. However, ellagic acid inhibited potently the activation of MAPKs. JNK, p38 and ERK1/2 MAPK protein activation was also detected in cytosolic extracts of normal colon mucosa by western blot using phosphospecific MAPK antibodies (Figs. 6A, 6B). To standardize protein loading in each line, blots were stripped and re-probed with the corresponding antibodies against both proteins. In the present study, phosphorylation of JNK and ERK1/2 protein was not detected in cytosolic extracts of normal colon mucosa, whereas a high expression appeared in colon mucosa from control TNBS-treated rats $(\mathrm{p}<0.001$ vs. sham group), indicating that both $\mathrm{JNK}$ and ERK1/2 protein activation could be induced at the acute stage of colonic lesion caused by TNBS. Nonetheless, upon treatment with ellagic acid the protein expression of $\mathrm{p}-\mathrm{JNK}$ and $\mathrm{p}-\mathrm{ERK} 1 / 2$ was 
significantly amielorated after 5 days of treatment $(\mathrm{p}<0.05$ and $\mathrm{p}<0.01$ vs. TNBS group) (Figs. 6A, 6B). According to p38 MAPK protein was highly increased by TNBS; nevertheless, oral administration of EA was able to diminish the upregulation of $\mathrm{p} 38$ MAPK protein (Figs. 6A, 6B).

\subsection{Ellagic acid inhibits NF-ҚВ-mediated transcriptional activation and IKK-Ba degradation in colonic mucosa of rats with acute TNBS-induced colitis.}

Since NF- $\kappa \mathrm{B}$ activity is controlled by the steady state level of $\mathrm{I} \kappa \mathrm{B} \alpha$, we further investigated the effect of ellagic acid on I $\kappa \mathrm{B}$ degradation in rat's colonic mucosa. As shown in Figure 7, protein extracts of colon tissues showed that intestinal inflammation of TNBS group induced a significant IкB degradation which is consistent with an upregulation of the NF-kappaB-binding activity. However, this was blocked by ellagic acid treatment. Moreover, ellagic acid treatment caused a significant inhibition of NFҚВ-mediated transcriptional activation. The nuclear translocation levels of p65 protein were increased in rats treated with TNBS. However, treatment with the polyphenolic compound prevented the TNBS-induced nuclear translocation level of p65 in colonic mucosa.

\section{DISCUSSION}

The results of the present study have revealed for the first time the beneficial effects of the ellagic acid, a polyphenol present in some fruits such as pomegranate, raspberries and nuts among others, in an experimental murine model of Crohn's disease. The administration of ellagic acid (10-20 mg/kg) diminished the severity and extension of the intestinal injuries induced by TNBS although there was no observed a significant dose-response. The reduction in the extension of the colitis accompanied a decrease in 
the loss of weight and a decrease in the relative weight/length of the colon. Likewise, an attenuation of relationship between the morphologic alterations associated with cellular injury, a good maintenance of the glandular architecture and an important decrease of inflammatory cells infiltrate were observed.

Ellagic acid also increased the amount of mucus stained by Alcian blue in colon mucosa. The protective effect of mucus as an active barrier may be largely attributed to its viscous and gel-forming properties which are derived from mucin glycoprotein constituents. Alcian blue-positive cells seem to be associated with regenerative processes of the mucosa [22] while reduction in the amount stained has been related to decreased resistance of the mucosa and paralleled by alterations in the normal pattern of maturation of the mucin in globbet cells [23].

Infiltration of leukocytes into the mucosa has been suggested to contribute significantly to the tissue necrosis and mucosal dysfunction associated with colitis as they represent a major source of reactive oxygen and nitrogen species in the inflamed colonic mucosa $[24,25]$. Reactive oxygen species and peroxynitrite induce cellular injury and necrosis via several mechanisms including peroxidation of membrane lipids, protein denaturation and DNA damage. Activated neutrophils produce superoxide anion, the main free radical in tissues, through NADPH oxidase which reduces molecular oxygen to the superoxide anion radical, and through the enzyme MPO which catalyzes the formation of such potent cytotoxic oxidants as hypochlorous acid from hydrogen peroxide and chloride ions and $N$-chloramines. In addition, neutrophils can also release proteases, lactoferrin and lipid mediators that can contribute to gastric injury [6].

In this respect, the injury associated with the instillation of the hapten was related to a significant increase of the activity MPO, indexed as neutrophil infiltration. 
On the contrary, the acute administration of ellagic acid significantly minimized the above mentioned parameter which might contribute, in addition to its antioxidant capacity, to an attenuation in the formation of oxygen and nitrogen free radicals. Our results are in agreement with previous reports from Ogawa et al. [15] and Singh et al. [16] with microspheres of ellagic and an ellagic acid rich fraction of Punica granatum extract in dextran sulphate sodium-induced colitis. In a similar way, there has also been described the protective effect of ellagic acid on gastric damage induced in ischemic rat stomachs following ammonia or reperfusion [26].

The antiinflammatory capacity of ellagic acid also has been revealed in allergic lung inflammation using a murine model of ovalbumin-induced asthma [8] and in pancreatic fibrosis in male Wistar Bonn/Kobori rats in which the protective effects were confirmed by an increase in pancreatic weight and decreases in myeloperoxidase activity [11].

Abnormal signalling pathways play an important role in the inflammatory process and can lead to dysregulation of the inflammatory response being crucial in the pathogenesis of IBD. The signalling pathways mainly include MAPKs, PI3K/Akt and NF-kappaB signalling pathways [27]. Three major groups of MAPKs have been identified in mammalian cells: the extracellular signal-regulated protein kinases (p42/44, also known as ERK), the p38 MAPK and the JNK [28]. These MAPKs require activation by phosphorylation to perform their intracellular signalling task.

In particular, p38 MAPK is a key modulator of several target genes that ultimately control infiltration of monocytic cells, acute intestinal inflammation and intestinal electrolyte and water secretion. They also regulate cytokine production in response to a variety of stimuli and up-regulate COX-2 expression in intestinal epithelial cells [29]. In addition to controlling the activity of leukocytes, MAPKs play a 
crucial role in the control of the activity of non-immune cells suggesting that their blockade could offer a molecular target for blockade of leukocyte recruitment to the intestine [30]

In particular, the importance of p38 MAPK in ulcerative colitis is supported by recent experiments where the use of p38 MAPK inhibitors abrogated colitis [31]. Moreover, a recent study has demonstrated that it can be effective for human IBD [32].

On the other hand, the JNK enzymes are regulated by Map/Erk kinase4 (MEK4) and MEK7 and they subsequently phosphorylate c-Jun enabling the activation of the activator protein 1 (AP-1) transcription factor that is known to be involved in the expression of many inflammatory genes [33]. Although their role in IBD is not well understood, there are recent reports of their activation in IBD tissue. For instance, Waetzig et al. [31] demonstrated that the activated form of JNK is up-regulated in patients with IBD. Mitsuyama et al. [34] presented similar findings, except that they identified the nucleus of epithelial and lamina propria mononuclear cells as the major source of activated MAPK in patients with IBD.

In further support of a direct role for JNK in intestinal pathophysiology, PARP$1^{-/-}$mice were noted to have less severe TNBS-induced colitis in association with reduced JNK and AP-1 DNA binding activity [35]. Besides, previous data from our research group found that the expression and activity of p38 and JNK were increased in rats with TNBS-induced colitis. This signal was significantly attenuated by curcumin, a component of the spice turmeric [36]. Recently it has been demonstrated that JNK inhibition using SB203580 was effective in reducing disease in dextran sulphate sodium -induced colitis [37]. Likewise Mitsuyama et al. [34] also described the ability of the JNK inhibitor SP600125 to prevent dextran sodium sulfate (DSS)-induced colitis in rats, suggesting a possible application of this category of drugs in the treatment of IBD. 
Our data are in agreement with the above studies providing new information regarding the role of activation of MAPK in the response of non-immune gut cells during mucosal inflammation such as that seen in patients with IBD.

The transcription factor NFkB consists of p50 and p65 heterodimer, which is retained in the cytoplasm by masking nuclear localization signal (NLS) by the inhibitor

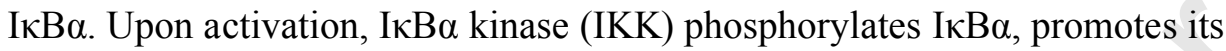
ubiquitination and degradation, thus allowing p50-p65 to translocate to the nucleus, bind to its consensus sequence, and induces transcription of genes essential for inflammation, immunoregulation, cell proliferation and survival. In addition, I $\mathrm{I} B \alpha \mathrm{I}$ is also able to enter the nucleus by itself and subsequently mediate the blockade of DNA-

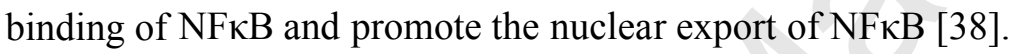

Classic activation of $\mathrm{NF \kappa B}$ can be initiated by a broad panel of different stimuli including bacterial cell wall components like lipopolysaccharide, pro-inflammatory cytokines like tumour necrosis factor (TNF)- $\alpha$ or interleukin (IL)-1, viruses and DNA damaging agents. Obviously the expression and activation of NFKB is strongly induced in the inflamed gut of IBD patients. Especially macrophages and epithelial cells isolated from inflamed gut specimens from IBD patients showed augmented levels of NFkB p65. Interestingly, the amount of activated NF- $\kappa B$ correlated significantly with the severity of intestinal inflammation [39]. As early studies revealed that (TNBS)-induced colitis could successfully be treated by local administration of p65 antisense oligonucleotides [40] the NFkB pathway soon became an attractive target for therapeutic interventions in IBD. Many of the already established immunosuppressive drugs in IBD like corticosteroids, sulfasalazine, methotrexate and anti-TNF- $\alpha$ antibodies are known to mediate their anti-inflammatory effects at least partly via inhibition of NFKB activity [38]. 
In our study, we describe for the first time that the protective effect of the ellagic acid in colonic inflammation was mediated through an inhibition of p38, JNK and ERK1/2 MAPKs and NF- $\kappa B$ signalling pathways. Both mechanisms seem to be functionally interconnected. Several publications demonstrated both routes converge on the control of the expression of genes involved in the inflammation and that p38 MAPK activation contributes to NF- $\kappa \mathrm{B}$ modulating the capacity of transactivación of its p65 subunit from the above mentioned factor transcripcional. The p65 subunit activation has significance in IBD because it is highly activated in the mucosal biopsy specimens of patients with ulcerative colitis and Crohn`s disease [41].

In the present study, we have also demonstrated that i) macroscopic damage was associated with both COX-2 and iNOS overexpression and ii) ellagic acid treatment reduced COX-2 and iNOS immunosignals to basal levels. Similar results have been obtained in previous in vivo experiments where ellagic acid has been shown to inhibit PGE2 release and PG-synthesising enzymes in human monocytes due to a suppressed expression of (COX)-2 and mPGEs-1 [9].

COX-2 and iNOS are enzymes that play a pivotal role in mediating inflammation [2]. In this regard, COX-2 activation produces excessive $\mathrm{PGE}_{2}$ and $\mathrm{TXB}_{2}$, which are important inflammatory mediators that contribute to the intestinal hyperemia, edema and even dysfunction, and iNOS activation leads to excessive production of NO which may be detrimental to the integrity of the colon based on the generation of reactive nitrogen species causing cellular degeneration in various tissues and contributing to the development of intestinal damage [42]. Additionally, iNOS acts in synergy with COX-2 to promote the inflammatory reaction $[43,44]$. Furthermore, both COX-2 and iNOS expression are upregulated by mitogen-activated protein kinases (MAPK) and NF-kB and AP-1 nuclear transcription factors in intestinal epithelial cells 
[43]. In fact, recent studies have identified IKK/NF- $\mathrm{BB}$ signalling in intestinal epithelial cells as an mandatory factor for the maintenance of epithelial integrity and immune homeostasis in the gut [45].

Altogether, our data suggest that treatment with ellagic acid was capable of preventing the degradation of the inhibitory protein IкB- $\alpha$, which inducing an inhibition of the nuclear transcription factor $\mathrm{NF}-\mathrm{\kappa B}$ activation and a subsequent reduction in the expression of both COX-2 and iNOS proteins.

In summary, is it possible that one of the underlying mechanisms implicated in the ellagic acid antiinflammatory effect in the present rat model of Crohn's disease, is comprised of a reduction of the neutrophilic infiltration in the colonic mucous accompanied by an increase in the production of mucus in goblet cells, in addition to a decrease of the expression of the pro-inflammatory proteins COX-2 and iNOS by inhibiting - NF-kappaB-mediated transcriptional activation as well as IKK-B $\alpha$ degradation and preventing $\mathrm{p} 38$, JNK and ERK1/2 MAPKs phosphorylation. Thereby suggesting that ellagic acid may be useful in treatment of ulcerative colitis.

\section{ACKNOWLEDGEMENTS}

Supported by funds from Junta de Andalucía and Ministerio de Ciencia e Innovación (AGL 2008-02475). AR gratefully acknowledges support from Fundación Farmacéutica Avenzoar Postgraduate fellowship from Colegio Oficial de Farmacéuticos de Sevilla (Spain). 


\section{REFERENCES}

[1] Uhlig HH, Coombes J, Mottet C, Izcue A, Thompson C, Fanger A, Tannapfel A, Fontenot JD, Ramsdell F, Powrie F. Characterization of Foxp3+CD4+CD25+ and IL10-secreting CD4+CD25+ T cells during cure of colitis. J Immunol 2006; 177:5852-60.

[2] O'Connor PM, Lapointe TK, Beck PL, Buret AG. Mechanisms by which inflammation may increase intestinal cancer risk in inflammatory bowel disease. Inflamm Bowel Dis 2010:16:1411-20.

[3] Xavier RJ, Podolsky DK. Unravelling the pathogenesis of inflammatory bowel disease. Nature 2007;448:427-34.

[4] Baumgart DC, Carding SR. Inflammatory bowel disease: cause and immunobiology. Lancet 2007;369:1627-40.

[5] Martín AR, Villegas I, Sánchez-Hidalgo M, Alarcón de la Lastra C. The effects of resveratrol, a phytoalexin derived from red wines, on chronic inflammation induced in an experimentally induced colitis model. Br J Pharmacol 2006;147:873-85.

[6] Sánchez-Hidalgo M, Martín AR, Villegas I, Alarcón de la Lastra C. Rosiglitazone, an agonist of peroxisome proliferator-activated receptor gamma, reduces chronic colonic inflammation in rats. Biochem Pharmacol 2005;69:1733-44.

[7] Hassoun EA, Vodhanel J, Abushaban A. The modulatory effects of ellagic acid and vitamin E succinate on TCDD-induced oxidative stress in different brain regions of rats after subchronic exposure. J Biochem Mol Toxicol 2004;18:196-203.

[8] Rogerio AP, Fontanari C, Borducchi E, Keller AC, Russo M, Soares EG, et al. Antiinflammatory effects of Lafoensia pacari and ellagic acid in a murine model of asthma. Eur J Pharmacol 2008;580:262-70. 
[9] Karlsson S, Nanberg E, Fjaeraa C, Wijkander J. Ellagic acid inhibits lipopolysaccharide-induced expression of enzymes involved in the synthesis of prostaglandin E2 in human monocytes. Br J Nutr 2010;103:1102-9.

[10] Chao PC, Hsu CC, Yin MC. Anti-inflammatory and anti-coagulatory activities of caffeic acid and ellagic acid in cardiac tissue of diabetic mice. Nutr Metab 2009;6:33. [11] Suzuki N, Masamune A, Kikuta K, Watanabe T, Satoh K, Shimosegawa T. Ellagic acid inhibits pancreatic fibrosis in male Wistar Bonn/Kobori rats. Dig Dis Sci 2009;54:802-10.

[12] Falsaperla M, Morgia G, Tartarone A, Ardito R, Romano G. Support ellagic acid therapy in patients with hormone refractory prostate cancer (HRPC) on standard chemotherapy using vinorelbine and estramustine phosphate. Eur Urol 2005;47:449-54. [13] Bell C, Hawthorne S. Ellagic acid, pomegranate and prostate cancer -- a mini review. J Pharm Pharmacol 2008;60:139-44.

[14] Glauert HP, Calfee-Mason K, Stemm DN, Tharappel JC, Spear BT. Dietary antioxidants in the prevention of hepatocarcinogenesis: a review. Mol Nutr Food Res 2010;54:875-96.

[15] Ogawa Y, Kanatsu K, Iino T, Kato S, Jeong YI, Shibata N, et al. Protection against dextran sulfate sodium-induced colitis by microspheres of ellagic acid in rats. Life Sci 2002;71:827-39.

[16] Singh K, Jaggi AS, Singh N. Exploring the ameliorative potential of Punica granatum in dextran sulfate sodium induced ulcerative colitis in mice. Phytother Res 2009;23:1565-74. 
[17] Shi XZ, Winston JH, Sarna SK. Differential immune and genetic responses in rat models of Crohn's colitis and ulcerative colitis. Am J Physiol Gastrointest Liver Physiol. 2011;300:G41-51.

[18] Morris GP, Beck PL, Herridge MS, Depew WT, Szewczuk MR, Wallace JL. Hapten-induced model of chronic inflammation and ulceration in the rat colon. Gastroenterology 1989;96:795-803.

[19] Bobin-Dubigeon C, Collin X, Grimaud N, Robert JM, Le Baut G, Petit JY. Effects of tumour necrosis factor-alpha synthesis inhibitors on rat trinitrobenzene sulphonic acid-induced chronic colitis. Eur J Pharmacol 2001;431:103-10.

[20] Grisham MB, Benoit JN, Granger DN. Assessment of leukocyte involvement during ischemia and reperfusion of intestine. Methods Enzymol 1990;186:729-42. [21] Bradford MM. A rapid and sensitive method for the quantitation of microgram quantities of protein utilizing the principle of protein-dye binding. Anal Biochem $1976 ; 72: 248-54$.

[22] Alarcón de la Lastra C, Martín MJ, Motilva V. Antiulcer and gastroprotective effects of quercetin: a gross and histologic study. Pharmacology 1994;48:56-62.

[23] Torres MI, Garcia-Martin M, Fernandez MI, Nieto N, Gil A, Rios A. Experimental colitis induced by trinitrobenzenesulfonic acid: an ultrastructural and histochemical study. Dig Dis Sci 1999;44:2523-29.

[24] Martín AR, Villegas I, La Casa C, Alarcon de la Lastra C. The cyclo-oxygenase-2 inhibitor, rofecoxib, attenuates mucosal damage due to colitis induced by trinitrobenzene sulphonic acid in rats. Eur J Pharmacol 2003;481:281-91.

[25] Martín AR, Villegas I, La Casa C, Alarcon de La Lastra C. Resveratrol, a polyphenol found grapes, suppresses oxidative damage and stimulates apoptosis during early colonic inflammation in rats. Biochem Pharmacol 2004;67:1399-410. 
[26] Lino T, Tashima K, Umeda M, Ogawa Y, Takeeda M, Takata K, et al. Effect of ellagic acid on gastric damage induced in ischemic rat stomachs following ammonia or reperfusion. Life Sci 2002;70:1139-50.

[27] Wei J, Feng J. Signalling pathways associated with inflammatory bowel disease. Recent Pat Inflamm Allergy Drug Discov 2010;4:105-17.

[28] Dong C, Davis RJ, Flavell RA. MAP kinases in the immune response. Annu. Rev. Immunol 2002;20:55-72.

[29] Kim GY, Kim KH, Lee SH, Yoon MS, Lee HJ, Moon DO, et al. Curcumin inhibits immunostimulatory function of dendritic cells: MAPKs and translocation of NF-kappa B as potential targets. J. Immunol 2005;174:8116-24.

[30] Scaldaferri F, Sans M, Vetrano S, Correale C, Arena V, Pagano N, et al. The role of MAPK in governing lymphocyte adhesion to and migration across the microvasculature in inflammatory bowel disease. Eur J Immunol 2009;39:290-300. [31] Waetzig GH, Seegert D, Rosenstiel P, Nikolaus S, Schreiber S. p38 mitogenactivated protein kinase is activated and linked to TNF-alpha signalling in inflammatory bowel disease. J. Immunol 2002;168:5342-51.

[32] Docena G, Rovedatti L, Kruidenier L, Fanning A, Leakey NA, Knowles CH, et al. Down-regulation of p38 mitogen-activated protein kinase activation and proinflammatory cytokine production by mitogen-activated protein kinase inhibitors in inflammatory bowel disease. Clin Exp Immunol 2010;162:108-15.

[33] Manning AM, Davis RJ. Targeting JNK for therapeutic benefit: from junk to gold? Nat.Rev. Drug Discov 2003;2:554-65.

[34] Mitsuyama K, Suzuki A, Tomiyasu N, Tsuruta O, Kitazaki S, Takeda T, et al. Proinflammatory signalling by Jun-N-terminal kinase in inflammatory bowel disease. Int. J. Mol. Med 2006;17:449-55. 
[35] Zingarelli B, Hake PW, Burroughs TJ, Piraino G, O'connor M, Denenberg A. Activator protein-1 signalling pathway and apoptosis are modulated by poly (ADPribose) polymerase-1 in experimental colitis. Immunology 2004;113:509-17. [36] Camacho-Barquero L, Villegas I, Sánchez-Calvo JM, Talero E, Sánchez-Fidalgo S, Motilva V, et al. Curcumin, a Curcuma longa constituent, acts on MAPK p38 pathway modulating COX-2 and iNOS expression in chronic experimental colitis. Int Immunopharmacol 2007;7:333-42.

[37] Assi K, Pillai R, Gómez-Muñoz A, Owen D, Salh B. The specific JNK inhibitor SP600125 targets tumour necrosis factor-alpha production and epithelial cell apoptosis in acute murine colitis. Immunology 2006;118:112-21.

[38] Atreya I, Atreya R, Neurath MF. NF-kappaB in inflammatory bowel disease. J Intern Med 2008;263:591-6.

[39] Rogler G, Brand K, Vogl D, Page S, Hofmeister R, Andus T, et al. Nuclear factor kappaB is activated in macrophages and epithelial cells of inflamed intestinal mucosa. Gastroenterology 1998;115:357-69.

[40] Neurath MF, Pettersson S, Meyer zum Buschenfelde KH, Strober W. Local administration of antisense phosphorothioate oligonucleotides to the p65 subunit of NFkappa B abrogates established experimental colitis in mice. Nat Med 1996;2:998-1004. [41] Vanden Berghe W, Plaisance S, Boone E, De Bosscher K, Schmitz ML, Fiers W, et al. p38 and extracellular signal-regulated kinase mitogen-activated protein kinase pathways are required for nuclear factor-kappaB p65 transactivation mediated by tumor necrosis factor. J Biol Chem 1998;273:3285-90.

[42] Talero E, Sánchez-Fidalgo S, Villegas I, de la Lastra CA, Illanes M, Motilva V. Role of different inflammatory and tumor biomarkers in the development of ulcerative colitis-associated carcinogenesis. Inflamm Bowel Dis 2011;17:696-710. 
[43] Itzkowitz SH: Molecular biology of dysplasia and cancer in inflammatory bowel disease. Gastroenterol Clin North Am 2006;35:553-71.

[44] Kraus S, Arber N. Inflammation and colorectal cancer. Curr Opin Pharmacol 2009;9:405-10.

[45] Pasparakis M IKK/NF- $\mathrm{B}$ signaling in intestinal epithelial cells controls immune homeostasis in the gut. Mucosal Immunology 2008; S54-57 


\section{FIGURE LEGENDS}

Figure 1. EA ameliorates acute TNBS-induced rat colitis. Effects of acute administration of EA on the colonic damage score. Colonic macroscopic damage resulting from TNBS (10 mg/animal) instilled into rat colon was scored as indicated in Section 2. Scores were quantified in the absence of treatment, or in the presence of EA (10 and $20 \mathrm{mg} / \mathrm{kg} /$ day p.o). Data are expressed as the mean \pm S.E.M.

*** $\mathrm{P}<0.001$, significantly different from Sham

${ }^{+} \mathrm{P}<0.05$, significantly different from TNBS

Figure 2. EA reduces histological damage. Histological appearance of rat colonic mucosa after haematoxylin and eosin stain (H-E), Alcian Blue stain (AB): Sham (A and B), and treated with TNBS $10 \mathrm{mg} / \mathrm{animal}$ (C and D), and EA $10 \mathrm{mg} / \mathrm{kg}$ p.o (E and F). A) and B) No histological modification was present in Sham animals. C) and D) Mucosal injury was produced after TNBS administration, characterized by necrosis of epithelium, focal ulceration of the mucoa and diffuse infiltration of inflammatory cells in the mucosa and submucosa. E) Treatment with EA $10 \mathrm{mg} / \mathrm{kg}$ p.o reduced the morphological alterations associated with TNBS administration protecting the mucosal architecture. F) Some areas showed accumulation of mucus and cell remnants; however, alcian blue positive- cells were less numerous and the mucin layer of the epithelium was missing. Original magnification $20 \times$.

Figure 3. EA reduces colonic infiltration in rat colon segments stained with Giemsa: Sham (A), and treated with TNBS $10 \mathrm{mg} / \mathrm{animal}$ (B), and EA $10 \mathrm{mg} / \mathrm{kg}$ p.o (C and D). Infiltration of inflammatory cells was highly observed in the colonic mucosa of 
TNBS-treated animals. EA prevented development of inflammatory changes. Original magnifications $20 \times$ and $40 \times$.

Figure 4. Inhibitory effect of acute EA treatment on myeloperoxidase activity (MPO) in TNBS-induced colitis model in rats. MPO activity (U/mg tissue) was increased after TNBS administration when compared with sham group. EA administration at both doses assayed, significantly decrease the MPO activity. $\mathrm{P}<0.001$, significantly different from Sham; ${ }^{+++} \mathrm{P}<0.001$, significantly different from TNBS

Figure 5. COX-2 and iNOS protein expressions are inhibed in colon tissue of TNBS-induced colitis by EA treatment. COX-2 and iNOS protein expressions were increased in TNBS group when compared with Sham animal. EA administration treatment diminished the expression of these both proteins. Densitometry was performed following normalization to the control ( $\beta$-actin house-keeping gene). Data are expressed as the means \pm S.E.M. ${ }^{* * *} \mathrm{P}<0.001$, significantly different from Sham; ${ }^{++}$ $\mathrm{P}<0.01$ and ${ }^{+++} \mathrm{P}<0.001$, significantly different from TNBS

Figure 6. Effects of EA on p-JUNK, p-p38 and p-ERK1/2 MAPKs signalling pathways in colon tissue of TNBS-induced colitis. The results are representative of three experiments performed on different samples. Densitometry was performed following normalization to the control (JUNK, p38 and ERK1/2 house-keeping genes, respectively). Data are expressed as the means \pm S.E.M. ${ }^{* *} \mathrm{P}<0.01$ and ${ }^{* * *} \mathrm{P}<0.001$, significantly different from Sham; ${ }^{+} \mathrm{P}<0.05$ and ${ }^{++} \mathrm{P}<0.01$ significantly different from TNBS 
Figure 7. EA treatment inhibits NF-ҚВ-mediated transcriptional activation and IKB $\alpha$ degradation in colonic mucosa of rats with acute TNBS-induced colitis. The results are representative of three experiments performed on different samples. Densitometry was performed following normalization to the control ( $\beta$-actin housekeeping gene). Data are expressed as the means \pm S.E.M. ${ }^{* *} \mathrm{P}<0.01$ and ${ }^{* * *} \mathrm{P}<0.001$, significantly different from Sham; ${ }^{+} \mathrm{P}<0.05,{ }^{++} \mathrm{P}<0.01$ and ${ }^{+++} \mathrm{P}<0.001$, significantly different from TNBS. 
Table 1. Quantified parameters after administration of EA (10 and $20 \mathrm{mg} / \mathrm{kg}$ p.o) in rats with acute colitis induced by TNBS intracolonic instillation (10 mg/animal).

\begin{tabular}{llllll}
\hline \multicolumn{1}{c}{ Group } & $\mathrm{n}$ & $\begin{array}{l}\text { Body weight } \\
\text { changes }(\mathrm{g})\end{array}$ & $\begin{array}{l}\text { Adhesions } \\
(\text { score 0-2) }\end{array}$ & $\begin{array}{l}\text { Diarrhoea } \\
\text { (score 0-1) }\end{array}$ & $\begin{array}{l}\text { Colon weight/colon } \\
\text { length }(\mathrm{mg} / \mathrm{cm})\end{array}$ \\
Sham & 9 & $27 \pm 5.28$ & 0 & 0 & $0.09 \pm 0.01$ \\
TNBS & 10 & $-10 \pm 4.78^{* * *}$ & $1.4 \pm 0.16^{* * *}$ & $0.81 \pm 0.12^{* * *}$ & $0.26 \pm 0.02^{* * *}$ \\
TNBS +EA 10 & 10 & $21.11 \pm 7.34^{++}$ & $1.3 \pm 0.15$ & $0.9 \pm 0.10$ & $0.20 \pm 0.02^{+}$ \\
TNBS + EA 20 & 10 & $39.56 \pm 4.76^{+++}$ & $1.4 \pm 0.26$ & $0.8 \pm 0.13$ & $0.20 \pm 0.01^{+}$
\end{tabular}

Data are expressed as mean \pm S.E.M.

${ }^{* * *} \mathrm{P}<0.001$, significantly different from sham

${ }^{+} \mathrm{P}<0.05,{ }^{++} \mathrm{P}<0.01$ and ${ }^{+++} \mathrm{P}<0.001$, significantly different from TNBS. 
Figure 1

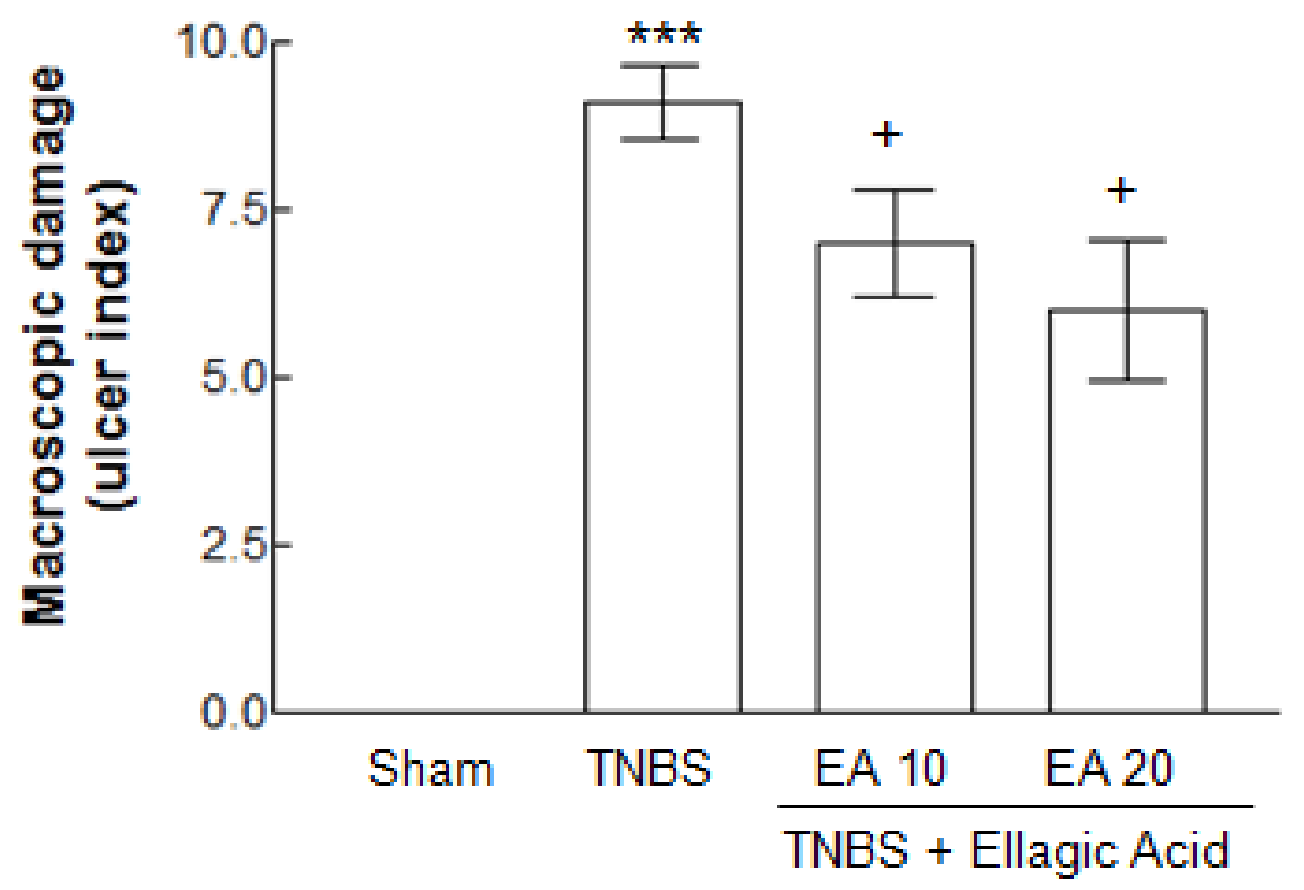


Figure 2
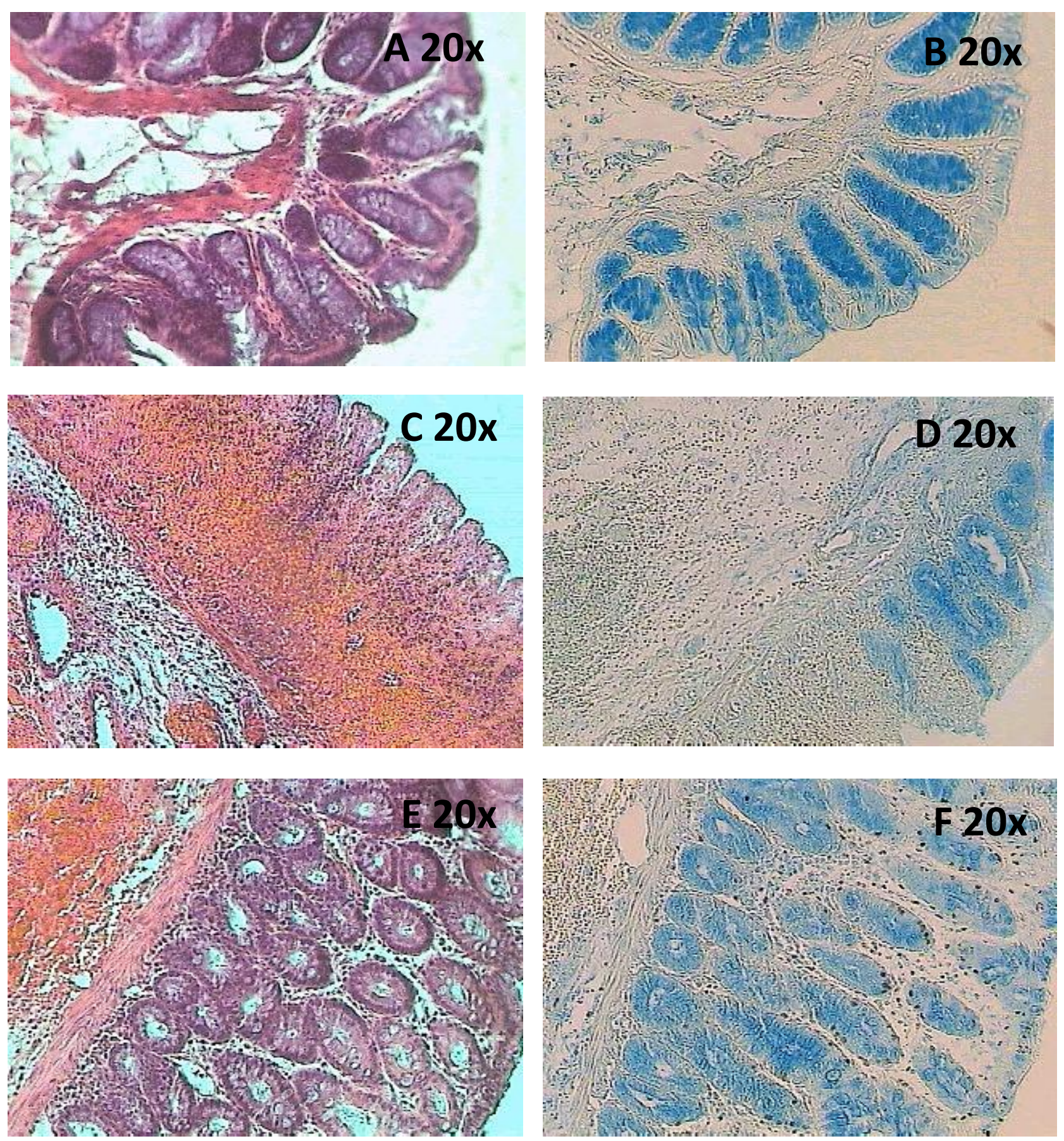


\section{Figure 3}
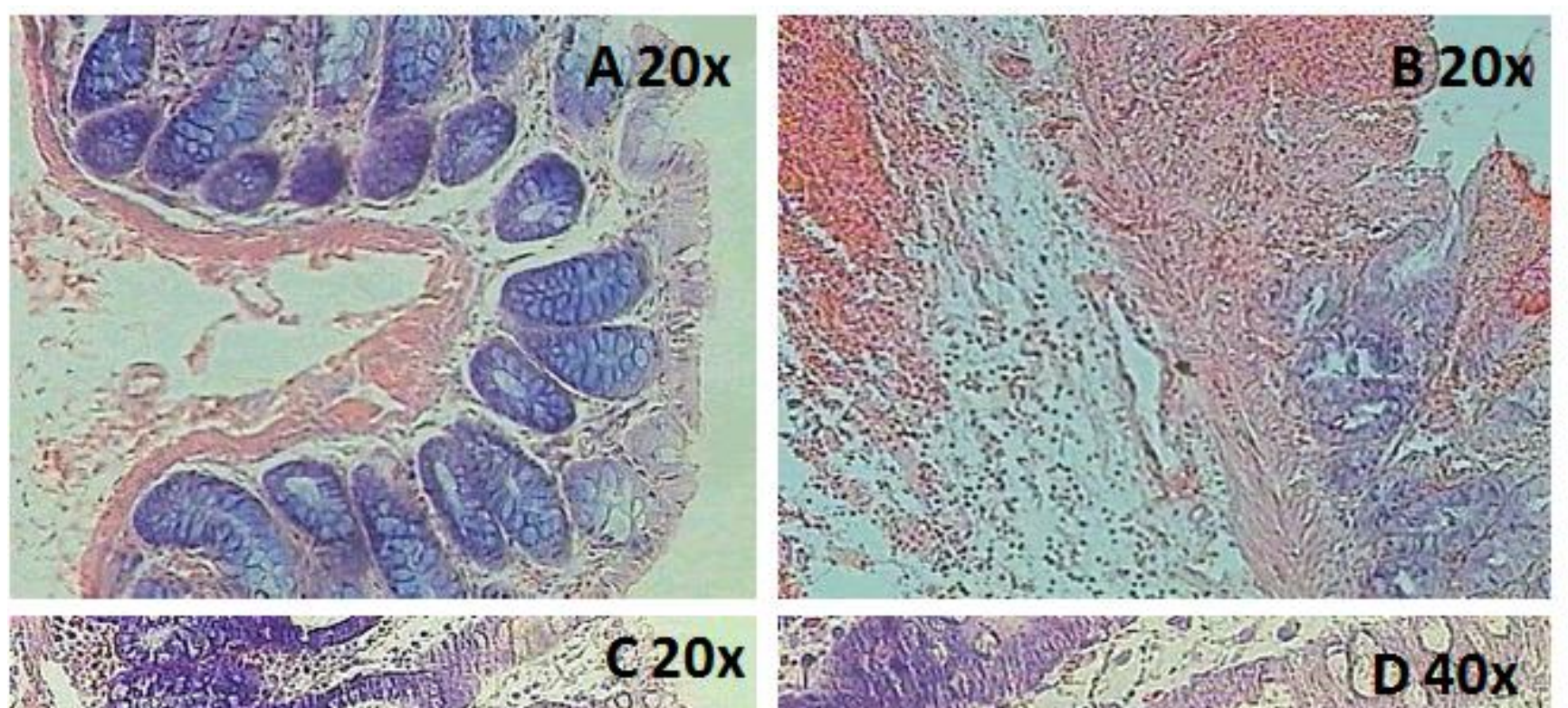
or 3 Th

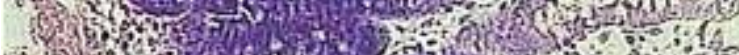

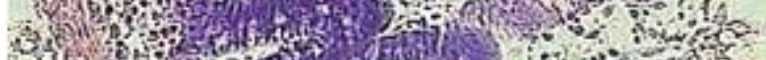

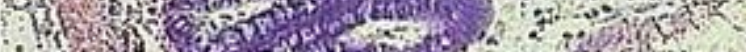

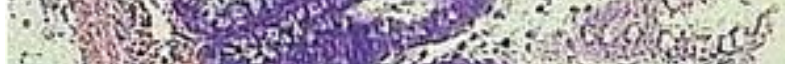
t. B. ? \& 4 H.

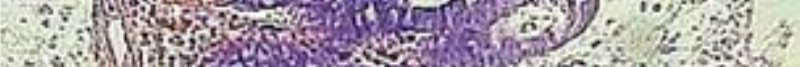

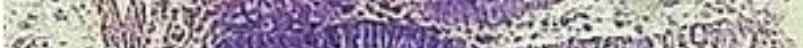
\& -2 ll

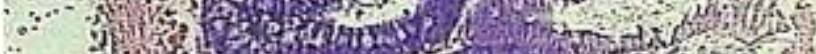

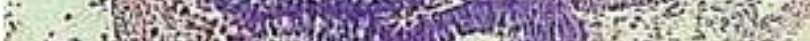
$\therefore \rightarrow$ S

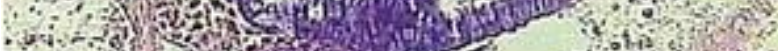

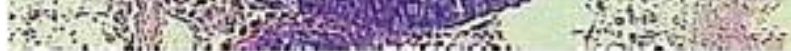

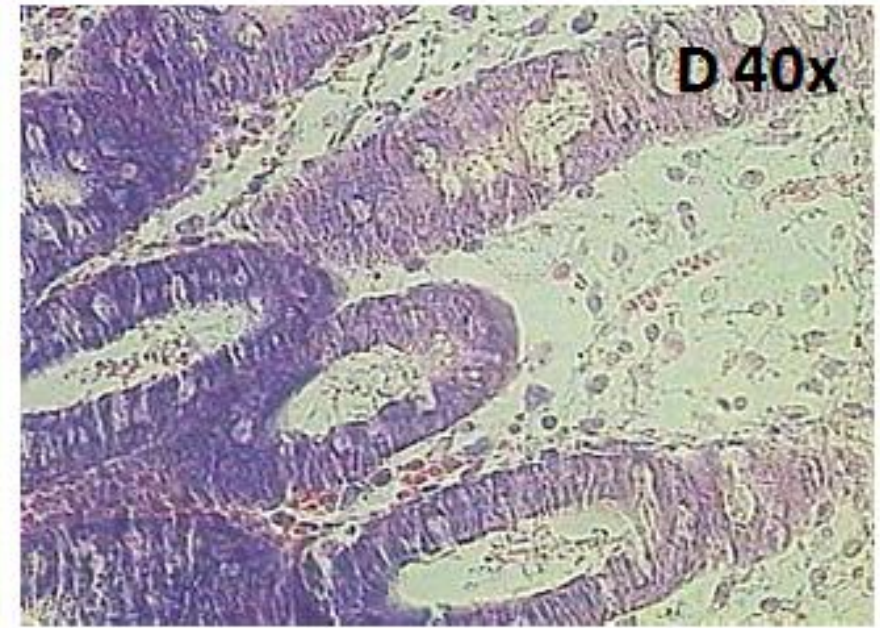


Figure 4

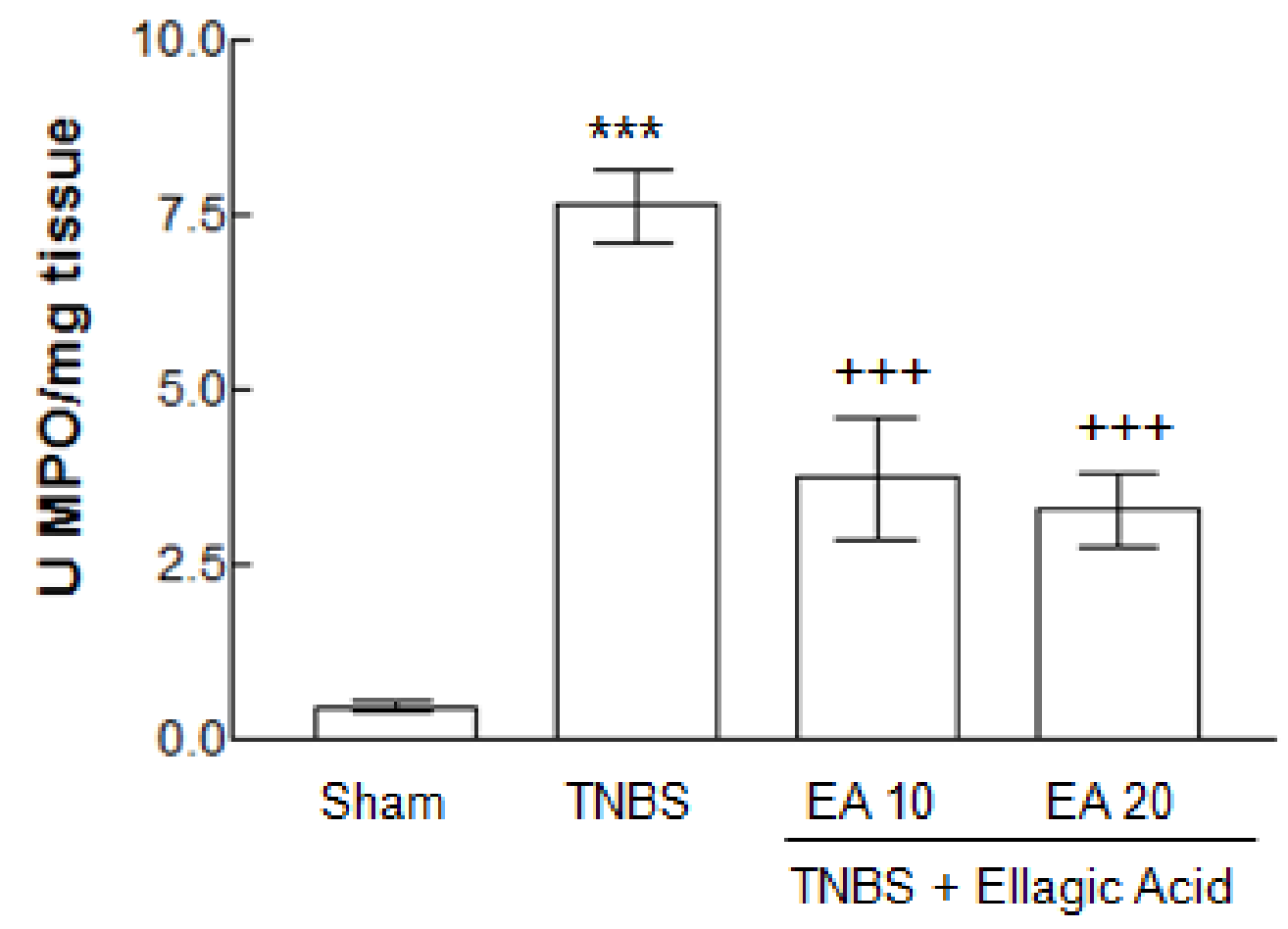


Figure 5

A

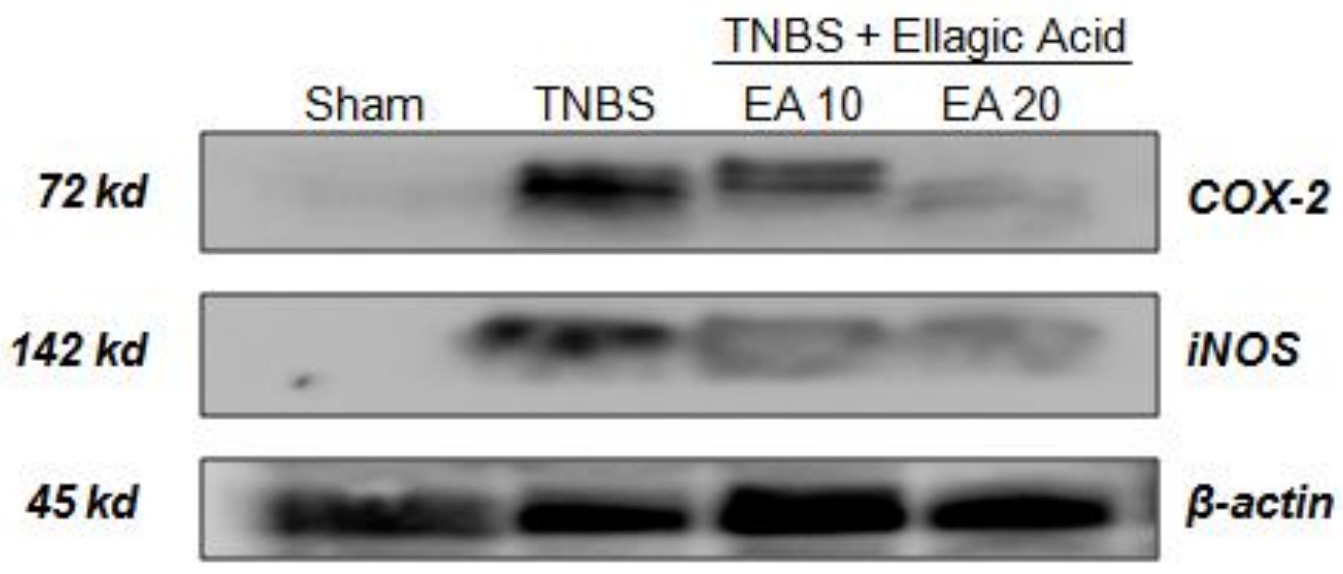

B

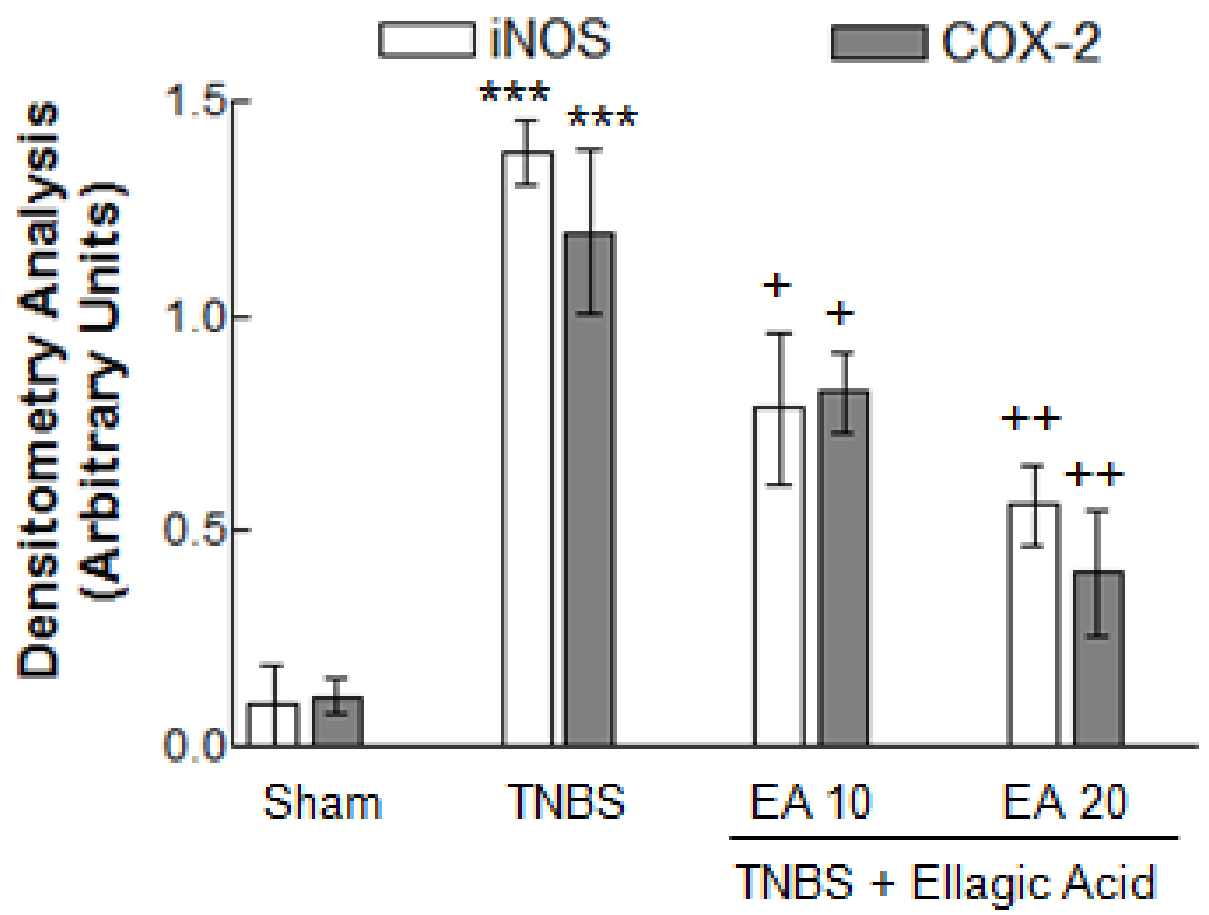


Figure 6

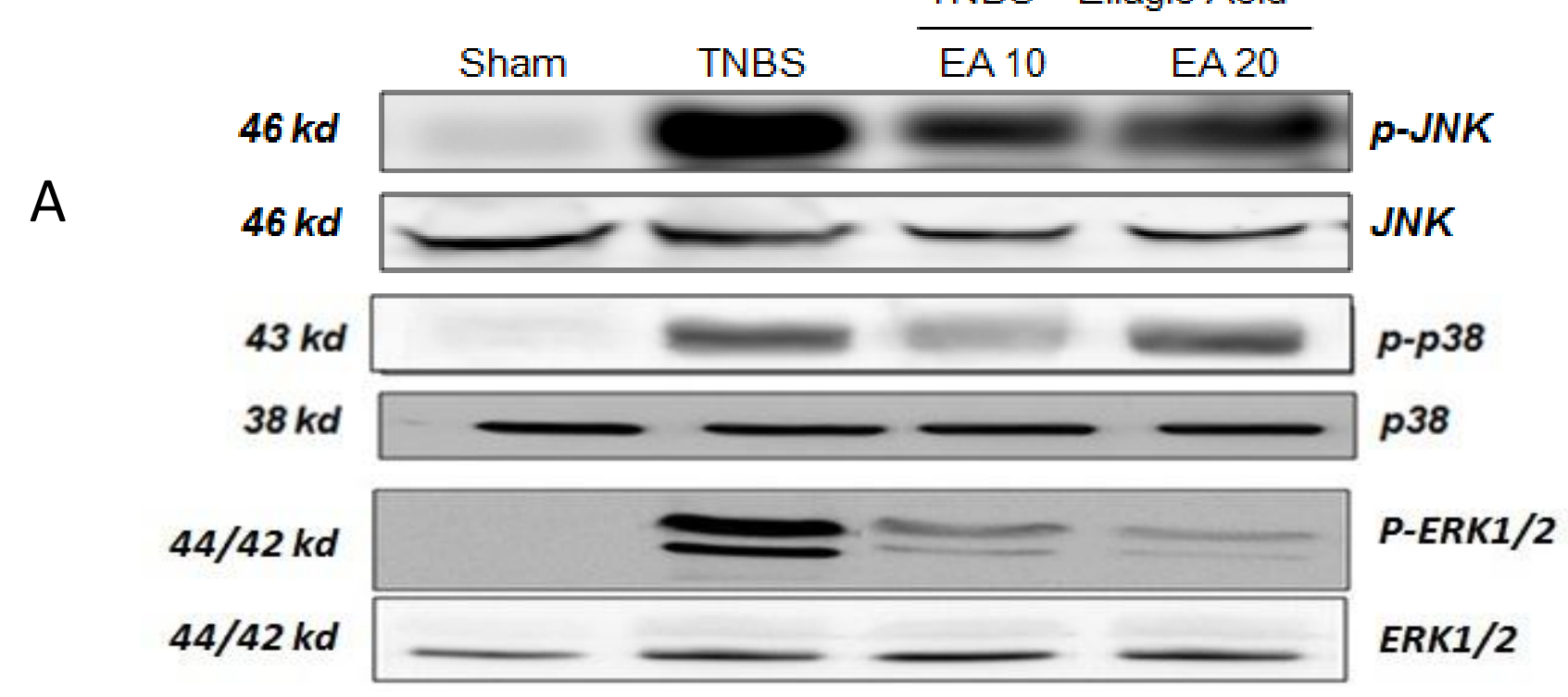

$\square$ p-JNK $\square$ p-p38 $\quad \mathbf{D}$ p-ERK1/2

B

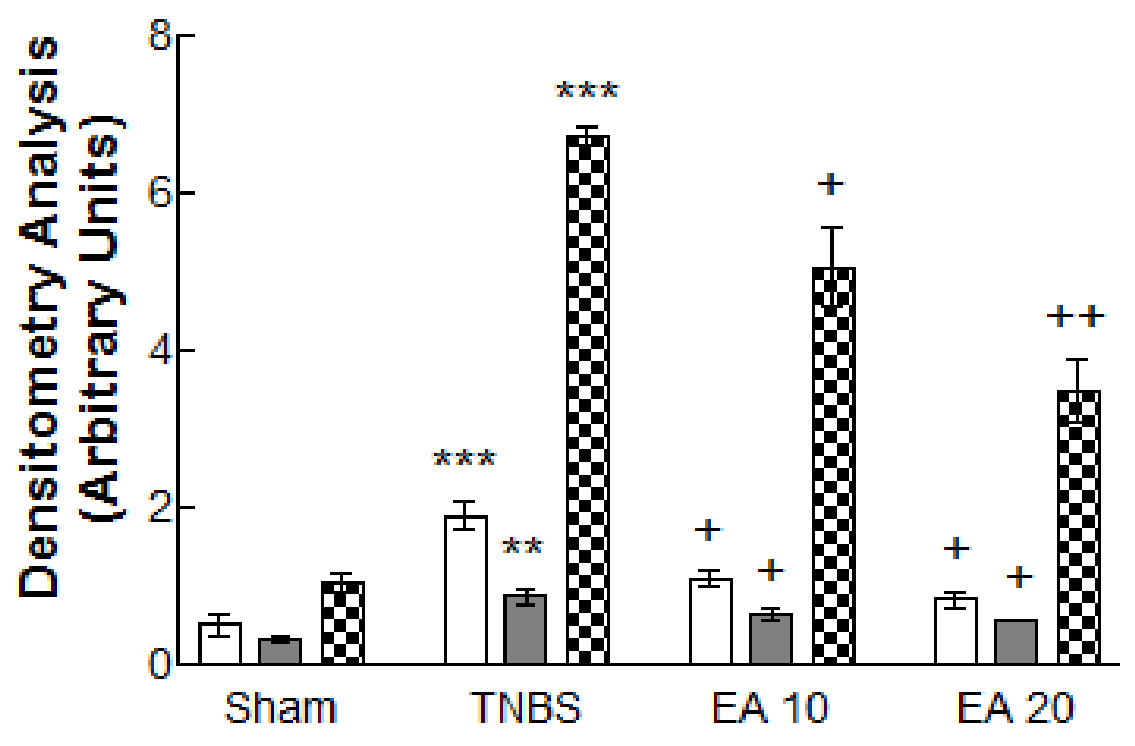


Figure 7

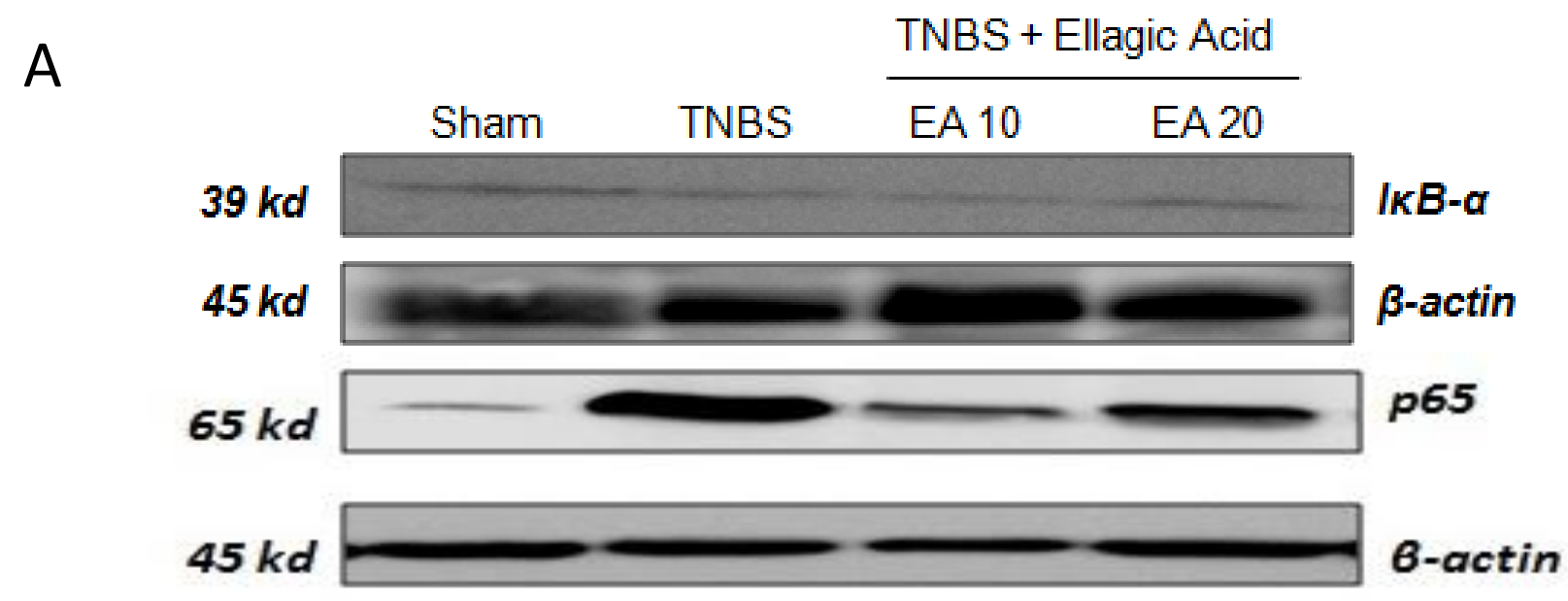

B

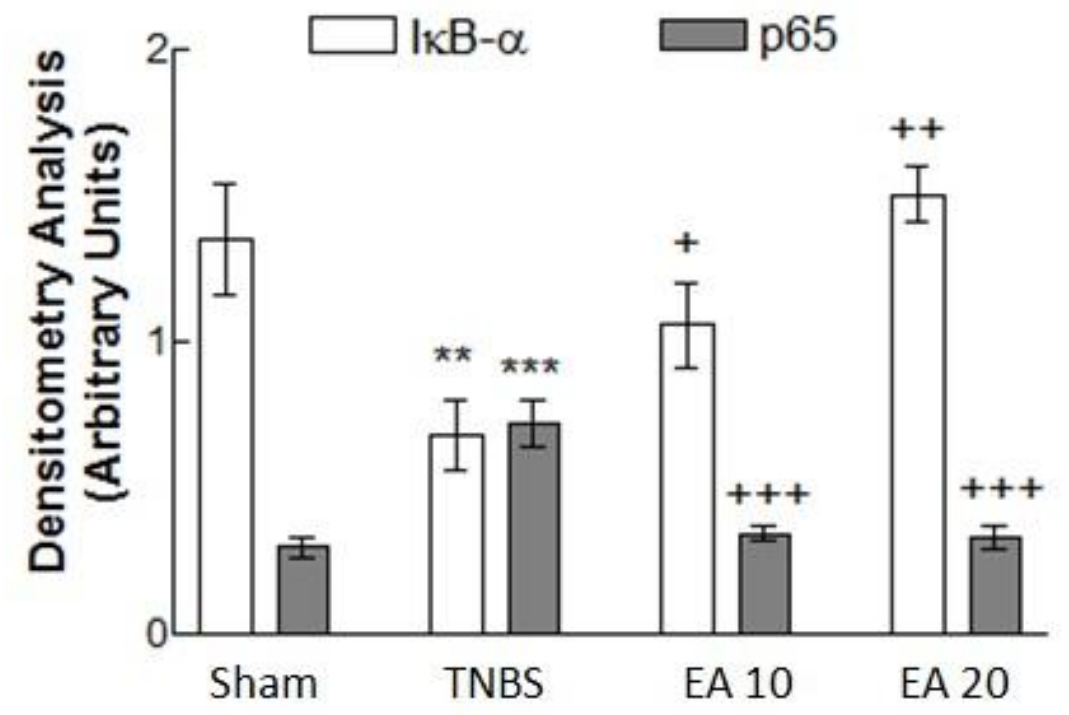




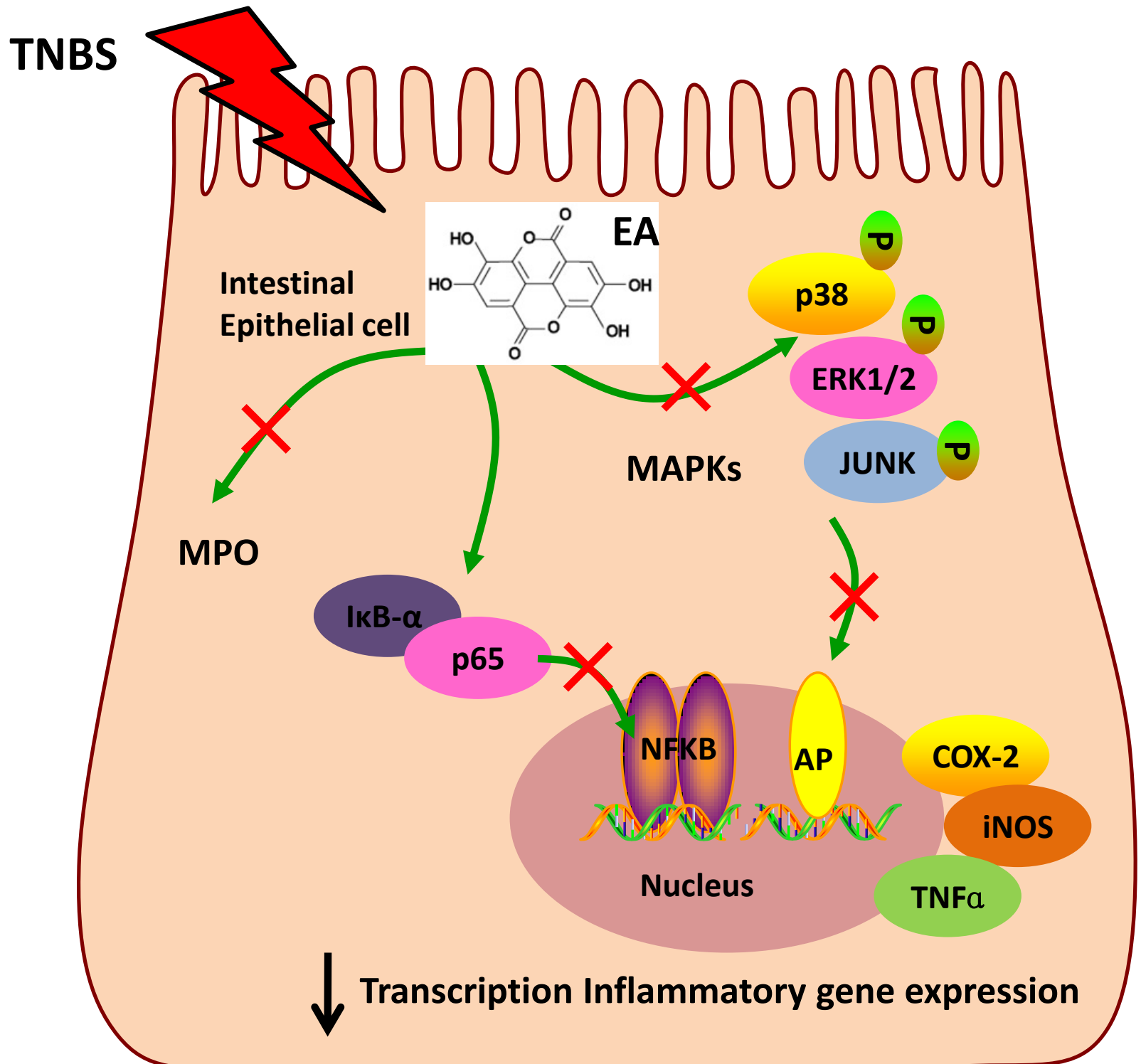

